young men, Mott's best-rewarded work has been done, most remarkably, in retirement - an exemplary encouragement to us all.

As for his method of creative reasoning, some clue may be gained from Smoluchowski's retrospective comment on the early days of solid state physics: "Mott... and his colleagues horrified us by their 'simple' visualizable and seemingly uncomplicated models and mathematics". So, with his models such as "swollen atoms", Mott is in a tradition expressed by H.G.J. Moseley in 1914: "the French point of view is essentially different from the English. Where we try to find models and analogies, they are quite content with laws". By his practice, then, Mott has a foot in one camp, and by his professed predilection for laws, also a foot in the other. Bestriding both, his is one of the most sustained lives of success in physics, recognized by numerous medals and 27 honorary doctorates.

A Life in Science is written with great economy, throwing laconic sidelights on many issues into which Mott's pursuit of science has drawn him. "Kindness with firmness" is a pervading trait, the former being exemplified in his remark that "The greatest pleasure in life is putting others on the way to success", the latter in stopping the project for a linear accelerator in Cambridge in one of his first acts as Cavendish professor.

In the deepening attention that many in science are giving to religion, Mott's own personal statements on the matter will be appreciated. In 1929 he wrote to his fiancée, "If you wanted to become a Roman Catholic, I should want to die. The trouble is that I can't think about the institution because it fills me with absolute physical disgust...". While this pristine view has been much mellowed by age and by an appreciation of the services performed by many devoted Catholics, "something of my antagonism remains". But Mott feels no such antagonism for the Anglican Church: indeed in retirement he has been baptized and confirmed as a member, and he devotes a whole chapter of the book to religion. He regularly attends church

finding it helpful to worship God in company with other people. If some things that are repeated in the Creed do not correspond with what I believe, such as 'born of the Virgin Mary', I accept what is said because to me the Christian religion is the sum of the beliefs of Christians throughout the ages, not only those of our present generation.

Each man's religion is a matter for himself, and we can only be grateful to one who has spent a long life so eminently in science for exposing so frankly his personal conviction.

R.V. Jones, 8 Queen's Terrace, Aberdeen ABI IXL. UK, is Emeritus Professor of Natural Philosophy in the University of Aberdeen.

\section{Getting the picture to tell the story}

\section{P.W. Hawkes}

Image Analysis: Principles \& Practice. Joyce-Loebl:1986. Pp.250. Pbk £35, $\$ 50$.

THERE are four grand themes of digital image processing: acquisition and coding; enhancement; restoration; and analysis, including pattern recognition. This last activity differs from the others in that the result is not a better image or one that is transformed in some way, but information about its contents. The information often comes in the form of a histogram or tables of data. In a karyogram, for example, the properties of the various chromosomes present might be listed; in quality control in a manufacturing process, certain dimensions might be monitored and the process interrupted if these exceeded preset limits; in aerial cartography, areas of forest and field, river and lake, factories and dwellings might be recognized, measured and their relative separations characterized in some way.

There have been many books on image analysis but none quite like this one - in

* Available from Rosalyn Kell, Joyce-Loebl, Marquisway, Team Valley, Gateshead, Tyne \& Wear NE1 I OQW, UK, or Bill Burnip, JoyceLoebl, c/o Nikon Inc., 623 Stewart Avenue, Garden City, New York 11530. USA.

\section{Disordered thoughts}

\section{P.W. Atkins}

The Unfinished Universe. By Louise B. Young. Simon \& Schuster:1986. Pp.239. $\$ 17.95$.

THE argument of this book is that a great creative process is taking place within the Universe, with us as witnesses and participants, and that matter has an innate tendency to achieve greater complexity. Form is emerging like a butterfly from a chrysalis, and the process that began when quarks coalesced into protons is now moving towards its culmination. The argument depends on a specific rejection of the view that the Universe is running down into a state of disorder.

The case in favour of this formative tendency is passionately argued, and it is plain from the style of the exposition that Mrs Young is deeply in love with the world and with her vision of science, and longs to share her wonder and awe. Such books should be approached with a special cast of mind, for it is important not to allow the style to obscure the content. This is espe- simple language, and with ample illustration, it enables the reader to use a commercial image analyser to the best advantage. The coverage is broad but is not correspondingly shallow, though the mathematical foundations of the various operations are rarely described. The text covers acquisition and digitization, but it will be used principally for its chapters on image processing, detection and measurement techniques. These introduce the reader to the ways of locating specific structures, of amending images by erosion or dilation (sic), of identifying and coding boundaries, and of characterizing shape, among many related topics. Subsequent chapters deal with colour images, computing (almost too brief to be useful) and a number of case studies. Each chapter ends with a bold-face summary; these read more like collections of great thoughts than scientific abstracts: "classification is a useful technique, but can become complex if many different kinds of measurements are used" gives an idea of their profundity.

Excusably, the anonymous authors had the Joyce-Loebl analyser in mind, but the book is not unduly partisan and gives an exceedingly clear and easily assimilated account of a great deal of disparate material. There is no better book for anyore involved with these machines who would be daunted by a more mathematical account.

P.W. Hawkes is Maitre de Recherche at the Laboratoire d'Optique Electronique du CNRS, BP 4347, F-31055, Toulose Cedex, France.

cially true of one wrapped in a jacket bearing messages from three highly respected scientists, one of whom claims that the book releases us from the stifling imprisonment of the Second Law of thermodynamics, another that Mrs Young's view that a creative process is taking place "is an idea... of great importance" and a third who finds it a strangely beautiful guide.

I feel outnumbered, for I find it none of these things. Passion there certainly is, and I can see why some might find the prose "lovely". I will disregard the little slips that don't matter very much (such as ascribing seven electrons to chlorine and the heat of the Earth to thermonuclear reactions in its core). I will also largely ignore (but it set my antennae waving) the author's rejection of the concept of force and its replacement by some kind of vague, non-quantified, tendency of particles to congregate into more complex form (p.41). I will concentrate instead on the central idea, that the Second Law cannot fully account for the phenomena of the world, and particularly for the phenomenon of life. Mrs Young admits (p.120) that the trend postulated by the Second Law is the opposite of the one she proposes, and therefore her thesis depends on 